\title{
A RECORD OF ARTHROBOTRYS TORTOR JAROWAJA AND ENGYODONTIUM ALBUM (LIMBER) DE HOOG FROM ANTARCTICA.
}

\author{
G. Caretta, G. Dell Frate \& Anna M. Mangiarotti. \\ Istituto di Micologia Medica "R. Ciferri e P. Redaelli'" \\ Via S. Epifanio, 14 - 27100 Pavia (Italy).
}

Palabras clave: Arthrobotrys tortor, Engyodontium album, suelos antárticos.

Key words: Arthrobotrys tortor, Engyodontium album, antarctic soils.

\section{SUMMARY}

We report for the first time isolates of Arthrobotrys tortor and Engyodontium album from Mid Victoria Land (Antarctica). These fungi are discussed with notes on their ecology.

\section{INTRODUCTION}

In a survey of microfungi in soil, mosses and ornithogenic material collected in Victoria Land (Antarctica) during the Italian expeditions 1988-89, 1989-90 and 1990-91, 269 isolates representative of 18 genera have been isolated. A preliminary listing was compiled in a previous paper (Del Frate and Caretta, 1990). Furthermore, a number of additional species of difficult identification was isolated, and from these entomogenous and nematophagous fungi: microscopic examination led to their attribution to the genus Engyodontium as $\mathbb{E}$. album (Limber) de Hoog, and Arthrobotrys as A. tortor Jarowaja, respectively. This is the first report of the observation of these two fungi from Antarctica.

We consider these records of particular taxonomical and ecological interest.

\section{MATERIAL AND METHODS}

Collections of material (212 samples) were made during the Italian expeditions 1988-91 at 7 locations of the Mid Victoria Land (Terra Nova), Ross Sector (160)$170^{\circ} \mathrm{E}$ ). The localities. the methods used for fungal

\section{RESUMEN}

[ Prineros aislanientos Antarticos de Arthrobotrys tortor Jarowaja y Engyodontium album (Limber) De Hoog. J

Se reporta por primera vez el aislamiento de Arthrobotrys tortor y Engyodontium album desde Mid Victoria Land (Antártica). Se discuten ambos taxa con algunos comentarios ecológicos.

isolation and identification have been described previously (Del Frate and Caretta, 1990). A good cultural medium suitable for isolation of some filamentous fungi, particularly the entomogenous and nematophagous ones, was the "moss plate culture". The moss used was Brachythecium rutabulum (Hedw.) Bruch et al., collected in the Pavia Botanical Garden; it was sterilized, placed in petri dishes and moistened with sterile water. The antarctic material was distributed on the surface of the moss plates, which were then incubated at various temperatures (8, 15,25 and $40^{\circ} \mathrm{C}$ ) for up to 12 weeks. This natural substrate has been found also to be suitable for the culture of Antarctic members of the keratinophilic fungi. Most of these fungi grow and sporulate in culture at temperatures in the range of $10-15^{\circ} \mathrm{C}$.

\section{RESULTS AND DISCUSSION}

Over 269 strains of fungi have been isolated from 212 samples of soil, mosses and ornithogenic material collected in 7 localities of the Mid Victoria Land.

In general the highest occurrences of fungi were recorded from mosses and soil when mosses were present. 
The nematophagous Arthrobotrys tortor and the entomogenous Engyodontium album, Acremonium strictum, Beauveria bassiana and Paecilomyces farinosus were isolated only or mainly from moss and soil-moss. Also the cellulolytic Chrysosporium verrucosum and Geomyces pannorum var. pannorum were isolated from mosses and ornithogenic material (feathers). Thelebolus microsporus, a minute 8-spore ascomycete (Montemartini Corte et al., 1993, Phome herbarum, ascomycetous yeast of the genus Torulopsis and basidiomycetous yeast of the genera Cryptococcus and Sporoboloweves were frequently isolated from bird dung.

\section{NEW RECORDS}

\section{Arthrobotrys iortor Jarowaja}

During investigations of hyphomycetes on mosses from Antarctica at Edmonson Point. Cape King. Mount Melbourne, numerous isolates were obtained in culture and found to possess conidiogenous structures and conidial morphology similar to A. tortor. Morphological investigations were carried out on moss plate cultures and on other agar plate formulations (OA, Sabouraud's agar. Emerson's agar medium): moss plate cultures proved to be particularly useful for the growth of this fungus. According to the original description and classification of A. tortor by Jarowaja (1968; 1970) our strains were identified as this species

According to Jarowaja (1968). A. tortor has a varied structure of the spore bearing part of the conidiophores. Conidiophores in A.tortor can be of the intermediate type between candelabrelloid and arthrobotryoid or genicularioid. with the apical part covered with short denticles. Heads of conidia rather elongated, somewhat irregular; conidia 20-26 long and (9) 11-1+ $\mu \mathrm{m}$ wide. hyaline, obovoidal to clavate. 2 -celle. with one median septum, slightly constricted at the septum. Sometimes the fungus forms small additional conidiophores bearing a loose apical verticillate head of 2-11 drop-like microconidia with one septum. Chlamydospores are often present, intercalary, solitary or arranged in short chains. Optimal growth was observed at $24^{\circ} \mathrm{C}$ and no development was found to occur at 6 or $30^{\circ} \mathrm{C}$.

According to Jarowaja (1968). A. tortor differs from A. conoides Drechsler in the morphology of conidia: the conidia of $A$. conoides are more slender. arise on blunt papillose sterigmata and are collected in regular apical and intercalary clusters. The fungus captures and eats eelworms (Nematoda).
In studies on the occurrence of predaceous fungi of the genus Arthrobotrys on various substrates in Poland, seven strains of $A$. tortor were isolated by Jarowaja (1970) from loess soil; two isolates trapped nematodes by means of predaceous bulb organs and haustoria.

Arthrobotrys tortor has not been recorded in other investigations on various substrata. Yet this species was listed by Schenck et al. (1977) among the 48 recognized species of the genus Arthrobotrys. Van Oorschot (1985) revised this genus and recognized 27 species and 5 varieties. Arthrobotrys tortor was listed by her as a synonym of $A$. conoides Drechsler. As we explained above, A. tortor differs sufficiently from $A$. conoides to warrant classification as a separate species. A.tortor and A. conoides differ mainly in the conidiophores. In $A$. tortor conidiophores of the intermediate type between candelabrelloid and arthrobotryoid or genicularioid are present: conidia are elongate. In $A$. conoides conidiophores proliferate repeatedly, conidia are elongateobovoidal and much longer 30-46 $\times 11.5-14 \mu \mathrm{m}$.

Nematophagous fungi have been recorded in soil and vegetation samples collected from various sites in Antarctica at $68^{\circ} \mathrm{S}$ (Gray and Smith. 1984). In 24 species of nematophagous fungi recorded, Arth robotrys robusta was reported as the only species of this genus. This species was only isolated from bird-associated sites. Spontaneous trap formation was widely observed in the Antarctic isolates and their distribution is most probably linked to the bird population (Gray, 1985).

A new springtail-predaceous hyphomycete of Gressittacanthis terranova isolated from moss species Bryum algens and Ceratodon purpureus in Antarctica was described as Arthrobotrys ferox by Onofri and Tosi (1992). It produces aerial predaceous organs consisting of ovoidal cells surrounded by an adhesive secretion and supporled by 2-cell stalks. Strains of $A$. tortor that we isolated in Antarctica are close to $A$. ferox, but they do not exhibit the peculiarity in culture of $A$. ferox to produce predaceous organs on the aerial hyphae. According to Onofri and Tosi (1992), the production of predaceous organs is very difficult. Further studies are required to fully evaluate this ability from our strains of Arthrobotrys. Besides the conidia of $A$. ferox are smaller than those of A. tortor.

Engyodontium album (Limber) de Hoog

The genus Engvodontium was erected by de Hoog (1978) to accommodate species in which some polyblastic conidiogenous cells with narrow denticles are formed. 
Seven species were included in this genus by de Hoog, being one of them E. album (Limber) de Hoog. This is a new combination erected by de Hoog for Tritirachium album Limber (basionym) and Beauveria alba (Limber) Saccas. This genus is characterized by hyaline, branched conidiophores, subverticillate to verticillate. polyblastic conidiogenouscells forming holoblastic one-cell-conidia on butt-shaped denticles on elongated rachids. Engyodontium is closely related to genus Tritirachium and shows features which link the anamorph genera Verticillium and Aphanocladium (Gams et al., 1984). Tritirachium Limber differs in pigmented colonies and regularly geniculate conidiiferous rachids with flat conidial scars. In E. album branching of conidiophore is strictly verticillate, rachids geniculate with regularly spaced and butt-shaped denticles concentrated in the apical region. The morphological characteristics of our isolates from Victoria Land (Antarctica) were very similar to $E$. album as reported by de Hoog. On moss plate culture and PDA our strains produce white colonies with abundant aerial mycelium. Conidiophores are ascendent to suberect. branching verticillate. conidiiferous rachids geniculate producing conidia from short denticles, conidia subulate to ellipsoidal, $2.5-3.5 \times 2-3 \mu \mathrm{m}$. The sympodial conidiogenous cells, or rachids, of the antarctic strains of $E$. album are longer. They are similar to the geniculate rachids of the genera Acrodontium and Tritirachium . that develop sympodially.

Engyodontium album is close to $E$. parvisporum (Petch) de Hoog: the main feature for distinguishing of both species is, according to de Hoog, the rachids, cylindrical, slightly flexuose with extremely thin denticles in E. parvisporum, with geniculate butt-shaped denticles on the edges in $E$. album.

The host of $E$. album strains isolated in Antarctica is difficult to determine. In this area the presence of collembola and mites has been confirmed. It is interesting to note how the nematophagous $A$. tortor and the entomogenous $E$. album, as well as Acremonium strictum, Beauveria bassiana and Paecilomyces farinosus appear to be a component of the mycota of this glaciated area. Their occurrence was found in Antarctica to be restricted to the mosses or the soil on which the mosses are present. Occurrence of these fungi on this substratum could be linked to collembola and nematode populations, colonists of this potentially favourable habitat, as it is the case with the bryoflora in Victoria Land consisting of sparsely developed communities of turf- and cushion-forming mosses (Broady et al.. 1987: Longton. 1973).

\section{ACKNOWLEDGMENTS}

We thank Dr. Walter Gams for his valuable suggestions and criticisms on this paper, colleagues S. Onofri, $\mathrm{O}$. Maggi and S. Sedmack who collected the samples in Antarctica, the National Programme of Antarctic Research for financial grant and the E.N.E.A. for technical support.

\section{REFERENCES}

Broady P., Given D., Greenfield L. and Thompson K. (1987) The Biota and enviroument of fumaroles on Mt. Melbourne, Northem Victoria Land. Polar Biology 7: 97-113.

Del Frate G. \& Caretta G. (1990) Fungi isolated from Antarctic material. Polar Biology 11: 1-7.

Gams W., Hoog G.S. de, Samson R.A. and Evans H.C. (1984) The hyphomycete genus Engyodontium. a link between Ierticillum and Aphanocladium. Persoonia 12: 135-147.
Gray. N, F. (1985) Nematophagous fungi from the maritime Antaretic: factors affecting distribution. Mycopathologia 90: 165-176.

Gray. N, F. \& Smith R.I.L. (1984) The distribution of nematophagous fungi in the maritime Antarctica. Mycopathologia 85: 81-92.

Hoog, G.S. de. (1972) The genera Beauseria, Isaria, Tritirachium and Acrodontium gen. nov: Studies in Mycology 1: 1-41.

(1978) Notes on some fungicolous Hyphomycetes and their relatives. Persoonial 10: 33-81. 
Jarowaja, N. (1968) Arthrobotrys tortor sp. nov. New predacious nematode-killing fungus. Acta mycologica. 4: 241-247.

(1970) The genus strthrobotrys. Acta mycologica 6:337406.

Longton, R. E. (1973) A classification of terrestrial vegetation near Mc Murdo Sound, continental Antaretica. Canadian Journal of Botany $51: 2339-2349$

Montemartini Corte, A.; Caretta, G. \& Del Frate, G. (1993) - Notes on Thelebolus microsporus isolated in Antaretica. Mycotaxon XLVIII: 343-358.
Onofri, S. \& Tosi S. (1992) Arthrobotrys ferox sp. nov., a springta capturing Hyphomycete from continental Antaretica. Mycotaxo 44: $445-451$

Oorschot, C.A.N. van. (1985) Taxonomy of the Dactylaria comple V. A review of Arthrobotry's and allied genera. Studies in Mycolog 26: 61-95.

Schenck, S.; Kendrick, W.B. \& Pramer, D. (1977) A new nematod trapping Hyphomycete and a reevaluation of Dactylaria an Arthrobotrys. Canadian Journal of Botany 55: $977-985$. 


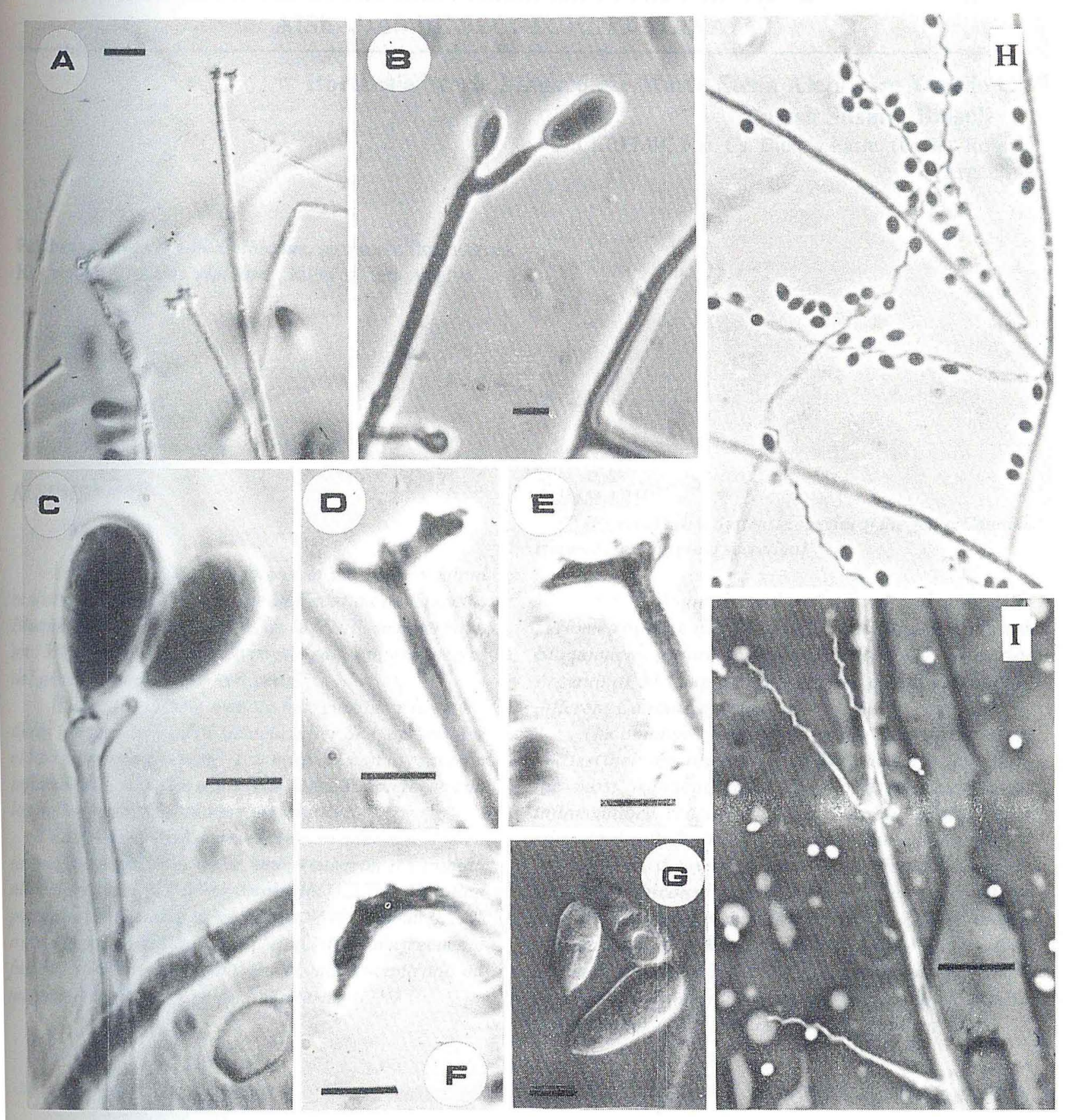

Fig. 1: Arthrobotrys tortor. Tips of conidiophores: A arthrobotryoid: B geniculariod: C, D, E candelabrelloid; $\mathbf{F}$ extended arthrobotryoid: $\mathbf{G}$ conidia. A. bars $=20 \mu \mathrm{m}$ : B-G. bars $=10 \mu \mathrm{m}$.

H-I. Engyodontium album; mono and birerticillate conidiophores: geniculate rachids with denticles. Bars $=10 \mu \mathrm{m}$ 